\title{
EXPOSURE TO EXCESSIVE SOUNDS DURING ORCHESTRA REHEARSALS AND TEMPORARY HEARING CHANGES IN HEARING AMONG MUSICIANS
}

\author{
EKSPOZYCJA NA ZA GŁOŚNE DŹWIĘKI PODCZAS PRÓB ORKIESTROWYCH \\ I CZASOWE ZMIANY SŁUCHU MUZYKÓW
}

Nofer Institute of Occupational Medicine / Instytut Medycyny Pracy im. prof. J. Nofera, Łódź, Poland

Department of Physical Hazards / Zakład Zagrożeń Fizycznych

\begin{abstract}
Background: It has been shown that musicians are at risk of noise-induced hearing loss. The aim of the study has been to evaluate the temporary changes of hearing in the case of orchestral musicians after group rehearsals. Material and Methods: The study group comprised 18 orchestral musicians, aged 30-58 years old (mean: 40 years old) having 12-40 years (mean: 22 years) of professional experience. The temporary changes in hearing after group rehearsals were determined using transient-evoked otoacoustic emissions (TEOAEs). Noise exposures during group rehearsals were also evaluated. Results: Musicians' hearing threshold levels were higher (worse) than expected for the equivalent non-noise-exposed population. Moreover, the high frequency notched audiograms were observed in some of them. After rehearsals, during which musicians were exposed to orchestral noise at A-weighted equivalent-continuous sound pressure level (normalized to 8-h working day) varied from 75.6-83.1 $\mathrm{dB}$ (mean: $79.4 \mathrm{~dB}$ ). The significant post-exposure reductions of TEOAE amplitudes (approx. $0.7 \mathrm{~dB}$ ) both for the total response and frequency bands of 2000 and $3000 \mathrm{~Hz}$ were noted. However, there were no significant differences between pre- and postexposure reproducibility of TEOAE. Conclusions: Obtained results have confirmed that orchestral musicians are at risk of hearing loss due to their professional activities, even at exposures to orchestral noise less than the limit values for occupational noise. Med Pr 2015;66(4):479-486
\end{abstract}

Key words: musicians, temporary changes in hearing, transient-evoked otoacoustic emission, TEOAE

\begin{abstract}
STRESZCZENIE
Wstęp: Wykazano, że muzycy narażeni są na ryzyko utraty słuchu wywołanej hałasem. Celem pracy była ocena czasowych zmian słuchu u muzyków orkiestrowych po udziale w próbach zespołowych. Materiał i metody: Badana grupa składała się z 18 muzyków orkiestrowych w wieku 20-58 lat (średnia: 40 lat) o stażu zawodowym 12-40 lat (średnia: 22 lata). Czasowe zmiany słuchu po próbach zespołowych wyznaczono na podstawie wyników badań emisji otoakustycznych przejściowych (transient-evoked otoacoustic emissions - TEOAE). Oceniono również poziom ekspozycji na hałas podczas prób zespołowych. Wyniki: Próg słuchu muzyków był wyższy (gorszy) niż oczekiwany w równoważnej populacji nienarażonej na hałas. Ponadto w audiogramach części muzyków zaobserwowano „załamki” typowe dla działania hałasu wysokoczęstotliwościowe. Po próbach zespołowych, podczas których muzycy byli narażeni na hałas orkiestrowy o poziomie ekspozycji na hałas odniesiony do 8-godzinnego dnia pracy (skorygowany charakterystyką częstotliwościową A) o wartościach 75,6-83,1 dB (średnia: 79,4 dB), zaobserwowano statystycznie istotne obniżenie amplitudy TEOAE (ok. 0,7 dB), zarówno w przypadku zbiorczej odpowiedzi, jak i w pasmach 2000 i $3000 \mathrm{~Hz}$. Nie stwierdzono jednak istotnych różnic między wynikami powtarzalności TEOAE przed ekspozycją i po ekspozycji. Wnioski: Uzyskane wyniki potwierdzają, że praca muzyków orkiestrowych wiąże się z ryzykiem uszkodzenia słuchu, nawet przy ekspozycji na hałas orkiestrowy nieprzekraczającej wartości dopuszczalnych dla hałasu w miejscu pracy. Med. Pr. 2015;66(4):479-486
\end{abstract}

Słowa kluczowe: muzycy, czasowe zmiany słyszenia, emisja otoakustyczna przejściowa, TEOAE

Corresponding author / Autor do korespondencji: Adam Dudarewicz, Nofer Institute of Occupational Medicine, Department of Physical Hazards, św. Teresy 8, 91-348 Łódź, Poland, e-mail: adudar@imp.lodz.pl Received: November 19, 2014, accepted: February 12, 2014

Funding / Finansowanie: the study was supported by the State Committee for Scientific Research, Poland (Grants no. IMP 18.5/2008-2010 „Evaluation of exposure to excessive sounds (noise) in classical orchestral musicians” and „Evaluation of exposure to excessive sounds (noise) in classical orchestral musicians”, grant manager: Małgorzata Pawlaczyk-Łuszczyńska, Ph.D., and IMP 18.2/2011 „Participation of individual rehearsals of professional orchestral musicians in the total exposure to sounds (noise) of professional musicians”, project manager: Adam Dudarewicz, Msc This paper was presented during the 16th International Conference on Noise Control NOISECONTROL 2013; 2013 May 26-29; Ryn, Poland. 


\section{INTRODUCTION}

Potential risk of noise-induced hearing loss due to loud music exposure has been widely investigated in musicians and people exposed to it. The result of surveys is ambiguous but it is supposed that the auditory symptoms are associated with exposure to music and that advanced audiological tests may be more useful for hearing tests of persons exposed to music, especially in the early stage of hearing damage. The review of research is presented in [1].

Orchestral musicians represent a professional group exposed to excessive sounds (so-called "orchestral noise") at levels exceeding permissible values for occupational noise. In spite of significant differences between the industrial noise and sounds that musicians are exposed to, many studies have shown changes in hearing caused by music [1-3]. Deterioration of musicians' hearing applies to both permanent and temporary changes in hearing $[1,4]$.

It is commonly known that exposure to excessive sounds (noise) may cause temporary changes in hearing. Moreover, it is believed that multiple and repeated exposure causes temporary changes leading to permanent hearing loss. Some studies have confirmed the presence of temporary threshold shift after usual musicians' activities, such as exercises, rehearsals and performances [5].

It has been suggested that otoacoustic emissions, particularly transient-evoked otoacoustic emissions (TEOAEs) are more sensitive in the assessment of auditory function than pure-tone audiometric one (PTA) and may be more useful for detecting both noise induced short-term hearing changes and early hearing loss [6].

The aim of this study has been to assess the temporary changes in hearing measured by means of the TEOAE after group rehearsals in the case of professional orchestral musicians.

\section{MATERIAL AND METHODS}

The study on temporary hearing changes caused by exposure to excessive sounds was conducted for a philharmonic orchestra during collective rehearsals. The study group comprised only professional musicians, who voluntarily decided to participate in hearing tests.

Participants included 18 musicians of philharmonic orchestras, aged 30-58 years old (mean: 40 years old), having 12-40 years (mean: 22 years) of professional experience. All of them were volunteers who did not report any health problems associated with hearing. The study group comprised a viola ( 2 persons), a flute ( 1 person), a harp (1 person), a violin (5 persons), an oboe (1 person) a clarinet (1 person), drums ( 2 persons), trombones ( 2 persons), a trumpet (1 person), and horns (2 persons).

All musicians filled a questionnaire developed to enable identification of occupational and non-occupational risk factors for noise-induced hearing loss (NIHL). The musicians' exposures to excessive sounds were assessed from the results of sound pressure level measurements which were performed during collective rehearsals that were preceded and followed by hearing tests. Those measurements were carried out according to the methods described in PN-N-01307 [7] and ISO 9612 [8] using Svantek analyzer type SVAN 958 (prod. Svantek, Poland) as an integrating-averaging sound level meter and Brüel and Kjær personal noise dose meters Bruel and type BK 4443.

The aforesaid sound pressure level measurements were performed in a rehearsal room during preparation for a concert aimed to present arias of Italian operas (by Giuseppe Verdi, Giacomo Puccini, Gioachino Rossini, etc.). The results of noise measurement and questionnaire were described in details elsewhere [9-11].

Musicians' hearing was assessed using both pure tone audiometry (PTA) and TEOAE before the start of rehearsals. The pure-tone audiometric tests were performed at audiometric frequencies: $1 \mathrm{kHz}, 2 \mathrm{kHz}, 3 \mathrm{kHz}$, $4 \mathrm{kHz}, 6 \mathrm{kHz}$, and $8 \mathrm{kHz}$ using a tonal audiometer Traveler Audio Audiometer type 222 (Interacoustics).

Immediately after the end of a rehearsal, i.e., after exposure to orchestral noise, the TEOAE tests were repeated. A scout otoacoustic emission system ver. 3.45.00 (Bio-logic System Corp.) was applied for recording and analyzing otoacoustic emissions. Transient-evoked otoacoustic emission recordings of 260 in average each were collected for every subject at stimuli levels of about $80 \mathrm{~dB}$, using standard clicks. The artefact rejection level was set at $20 \mathrm{mPa}$. Each response was windowed 3.5-16.6 ms post stimulus and band-pass filtered $0-6000 \mathrm{~Hz}$. The whole TEOAE response in the frequency band $1-4 \mathrm{kHz}$ and the TEOAE amplitude levels for frequency bands with central frequencies $1 \mathrm{kHz}, 1.5 \mathrm{kHz}$, $2 \mathrm{kHz}, 3 \mathrm{kHz}$ and $4 \mathrm{kHz}$ were examined. Both hearing tests were carried out in a philharmonic building, in a quiet room where the A-weighted sound pressure level of background noise did not exceed $35 \mathrm{~dB}$.

Audiograms were used for the purpose of verification of musicians' self-reported hearing status. In ad- 
dition, the actual audiometric hearing threshold levels determined in orchestral musicians were compared with the predicted hearing loss according to ISO 1999 [12].

Due to the large number of factors that may affect the results of TEOAE performed before and after exposure to noise orchestra, in this study, the effect of risk factors, other than exposure to noise, have not been taken into account because of a small size of the study group and the significant variation in the status hearing subjects.

Statistical analysis of temporary changes in the TEAOE amplitude levels and signal to noise ratio (at frequency bands of $1000 \mathrm{~Hz}, 1500 \mathrm{~Hz}, 2000 \mathrm{~Hz}, 3000 \mathrm{~Hz}, 4000 \mathrm{~Hz}$ and for total response) was made using non-parametric tests for the dependent variables, i.e., Wilcoxon matched pair and Sign tests. Cases with the TEOAE amplitude below noise level were excluded from the analysis.

The differences between post- and pre-exposure amplitudes of TEOAE were evaluated using linear regression (at different frequencies and for total response). The intercept of the linear function with post exposure TEOAE amplitude axis was interpreted as the average change in the amplitude of TEOAE caused by exposure to orchestral noise in the study group.

All statistical tests were made with an assumed level of significance $\mathrm{p}<0.05$. The STATISTICA (version 6.1) software package was employed for the purpose of the statistical analysis of the data.

The study protocol was approved by the Ethics Committee of the Nofer Institute of Occupational Medicine, Łódź, Poland (decision No. 9/2010) and all subjects gave their written consents for participation in the examinations.

\section{RESULTS}

According to our previous results, musicians playing various instruments are subjected to varying exposures to sounds. These exposures vary considerably over time, and strongly depend on the repertoire. In order to illustrate the levels of noise, to which the musicians are exposed while playing instruments, the Table 1 presents aggregate results of measurements of sound pressure levels at positions of musicians playing various instruments [9-11].

The details concerning the study group including A-weighted noise exposure level normalized to a 40-h nominal working week $\left(\mathrm{L}_{\mathrm{EX}, \mathrm{W}}\right)$ with respect to a weekly time of playing instruments declared by musicians) are shown in the Table 2 . The $\mathrm{L}_{\mathrm{EX}, \mathrm{w}}$ values were estimated based on the results of our previous studies [9-11] and on a weekly time of playing an instrument declared by musicians. This table also presents data on the A-weighted noise exposure level during analyzed rehearsals (between TEOAE tests) normalized to a nominal 8-h working day $\left(\mathrm{L}_{\mathrm{EX}, 8 \mathrm{~h}}\right)$. As it has been proven, during rehearsals the study subjects were exposed to orchestral noise at levels below the limit values for occupational noise $(<85 \mathrm{~dB})$.

It was found that 5 subjects had notched audiograms at high frequencies. The notched audiograms were the

Table 1. Sound pressure levels measured during group rehearsals in orchestral musicians [9-11]

Tabela 1. Poziom ciśnienia akustycznego zmierzony podczas prób grupowych muzyków orkiestrowych [9-11]

\begin{tabular}{|c|c|c|c|}
\hline Instrument & $\begin{array}{c}\mathrm{L}_{\mathrm{Aeq}, \mathrm{T}}+\mathrm{U} \\
{[\mathrm{dB}]}\end{array}$ & $\begin{array}{c}\mathrm{L}_{\text {Amax }} \\
\text { (range) } \\
\text { (zakres) } \\
\text { [dB] }\end{array}$ & $\begin{array}{c}\mathrm{L}_{\text {Cpeak }} \\
\text { (range) } \\
\text { (zakres) } \\
{[\mathrm{dB}]}\end{array}$ \\
\hline Violin / Skrzypce & $84.6+2.7$ & $90.6-107.1$ & $106.6-131.8$ \\
\hline Viola / Altówka & $84.7+3.0$ & $89.9-105.9$ & $104.4-120.8$ \\
\hline Oboe / Obój & $88.1+3.6$ & $95.7-108.3$ & $112.5-124.7$ \\
\hline Flute / Flet & $87.8+4.0$ & $94.7-109.2$ & $106.8-133.5$ \\
\hline Trombone / Puzon & $90.1+4.8$ & $96.1-111.2$ & $115.7-128.3$ \\
\hline Percussion / Perkusja & $87.1+4.0$ & $86.7-112.0$ & $105.0-135.5$ \\
\hline
\end{tabular}


Table 2. Characteristics of the study group

Tabela 2. Charakterystyka badanej grupy

\begin{tabular}{|c|c|c|c|c|c|c|c|}
\hline \multirow[t]{2}{*}{$\begin{array}{l}\text { Variable } \\
\text { Zmienna }\end{array}$} & \multicolumn{2}{|c|}{$\begin{array}{c}\text { Respondents } \\
\text { Badani } \\
(\mathrm{N}=18)\end{array}$} & \multicolumn{5}{|c|}{$\begin{array}{l}\text { Percentile } \\
\text { Percentyl }\end{array}$} \\
\hline & M & $\mathrm{SD}$ & 10 & 25 & 50 & 75 & 90 \\
\hline Age [years] / Wiek [w latach] & 39.4 & 9.6 & 30.0 & 32.0 & 36.0 & 44.0 & 56.0 \\
\hline Duration of a musician's activity [years] / Okres aktywności muzycznej [w latach] ${ }^{1}$ & 23.7 & 8.1 & 15.0 & 17.0 & 23.0 & 30.0 & 33.0 \\
\hline Time of playing an instrument [h/week] / Czas gry na instrumencie [godz./tydzień] & 29.3 & 5.2 & 20.0 & 28.0 & 30.0 & 32.0 & 35.0 \\
\hline $\mathrm{L}_{\mathrm{EX}, 40 \mathrm{~h}}[\mathrm{~dB}]^{2}$ & 84.3 & 2.6 & 81.5 & 82.5 & 84.4 & 86.2 & 87.8 \\
\hline $\begin{array}{l}\text { Time of exposure to excessive sounds (music during rehearsals) / } \\
\text { / Czas ekspozycji na za głośne dźwięki (na muzykę w czasie prób) [min }]^{3}\end{array}$ & 182.0 & 76.0 & 91.0 & 133.0 & 189.0 & 243.0 & 272.0 \\
\hline $\mathrm{L}_{\mathrm{EX}, 8 \mathrm{~h}}[\mathrm{~dB}]^{4}$ & 79.4 & 3.8 & 76.5 & 77.8 & 80.1 & 81.9 & 83.1 \\
\hline
\end{tabular}

M - mean / średnia, SD - standard deviation / odchylenie standardowe.

${ }^{1}$ Including college period (5 years) / W tym okres studiów (5 lat).

${ }^{2}$ A-weighted noise exposure level normalized to a 40-h nominal working week (with respect to weekly time of playing instruments declared by musicians) / Poziom ekspozycji na hałas odniesiony do 40-godzinnego tygodniowego wymiaru czasu pracy (z uwzględnieniem tygodniowego czasu gry na instrumentach deklarowanego przez muzyków).

${ }^{3}$ Time between transient-evoked otoacoustic emissions (TEOAE) tests / Czas między badaniami emisji otoakustycznych przejściowych (TEOAE).

${ }^{4} \mathrm{~A}$-weighted noise exposure level (between TEOAE tests) normalized to a nominal 8-h nominal working day / Poziom ekspozycji na hałas (między badaniami TEOAE) odniesiony do 8-godzinnego dobowego wymiaru czasu pracy.

ones, in which the differences between the maximum hearing threshold at frequencies $3 \mathrm{kHz}, 4 \mathrm{kHz}, 6 \mathrm{kHz}$ and hearing thresholds at frequencies 2 and $8 \mathrm{kHz}$ were greater than or equal to $10 \mathrm{~dB}$.

Generally, the averaged audiometric hearing threshold levels of the 18 musicians (36 ears) do not exceed $15 \mathrm{~dB}$ HL, which indicates a good state of their hearing (Figure 1). Higher hearing threshold levels at the frequencies of $4000 \mathrm{~Hz}, 6000 \mathrm{~Hz}$ and $8000 \mathrm{~Hz}$ were only observed in the case of subjects over the age of 40 years old.
Musicians' hearing threshold levels (at 2000, 4000 and $6000 \mathrm{~Hz}$ ) were higher than expected for age- and gender-comparable non-noise-exposed population according to ISO 1999 [12]. The observed increase in hearing thresholds below $1500 \mathrm{~Hz}$ was probably related to the conditions, under which hearing tests were conducted, i.e., in a quiet room (with background noise up to $35 \mathrm{~dB}(\mathrm{~A})$ ) in the philharmonic building instead of a sound-proof cabin.

The TEOAE results are presented in the Table 3 and Figures 2-4. As it has been proven, the TEOAE amplitude reduction was observed at all tested frequencies.

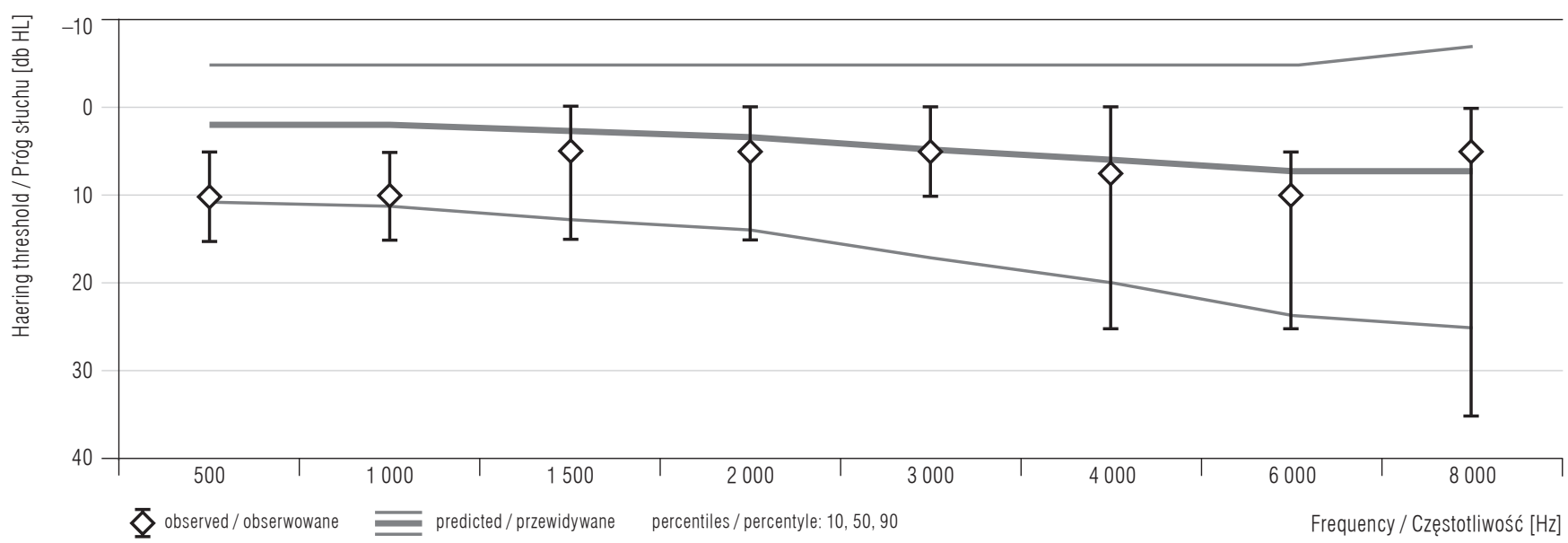

Fig. 1. The hearing threshold level in the study group compared to predicted hearing threshold levels according to ISO 1999 [12] in non-exposed noise population (data base A)

Ryc. 1. Progi słuchu w badanej grupie w porównaniu z przewidywanymi progami słuchu według ISO 1999 [12] w populacji nienarażonej na hałas (baza danych A) 


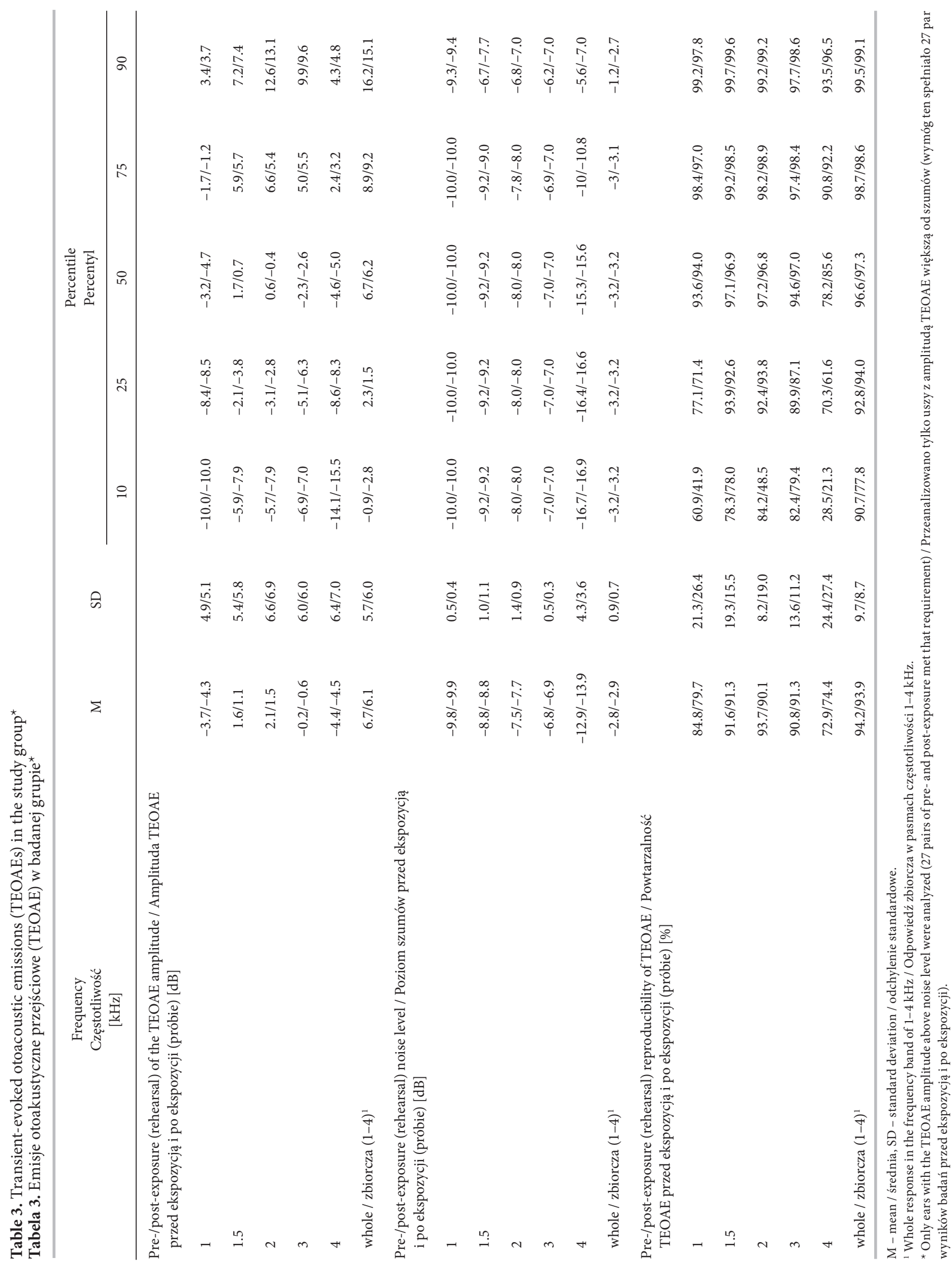




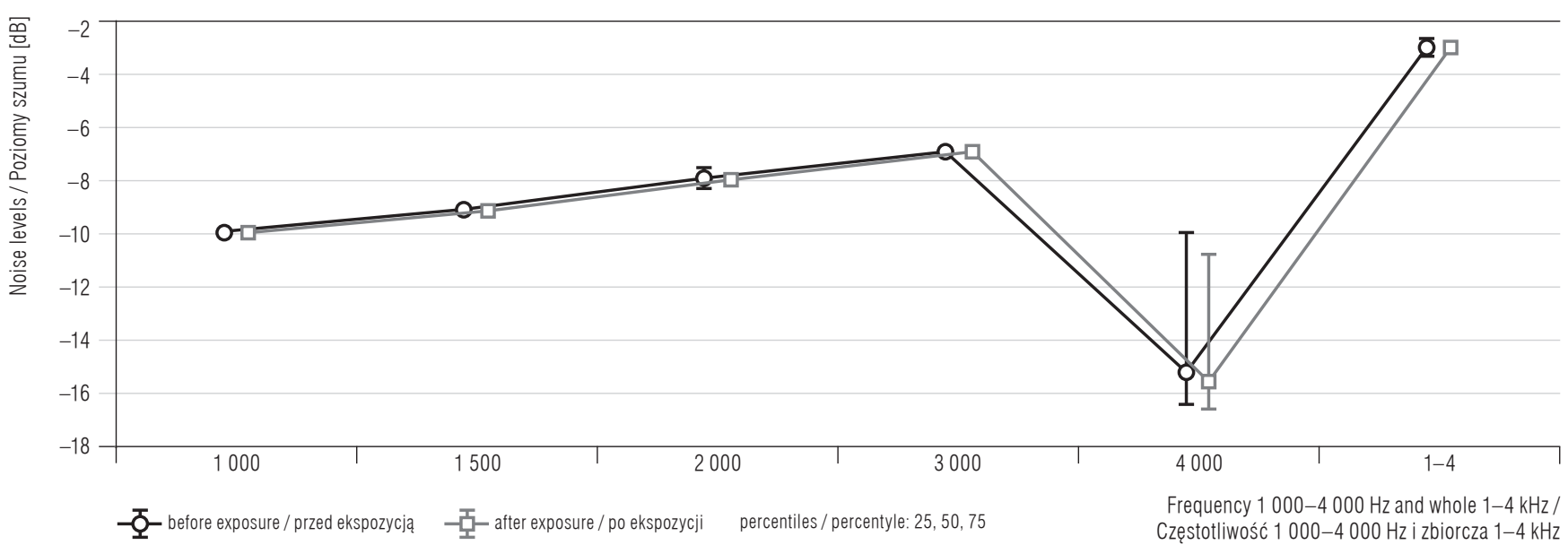

Fig. 2. Transient-evoked otoacoustic emissions (TEOAEs) tests - comparison of noise levels before and after exposure (playing instruments) Ryc. 2. Badanie emisji otoakustycznych przejściowych (TEOAE) - porównanie poziomu szumów przed ekspozycją i po ekspozycji (grze na instrumentach)

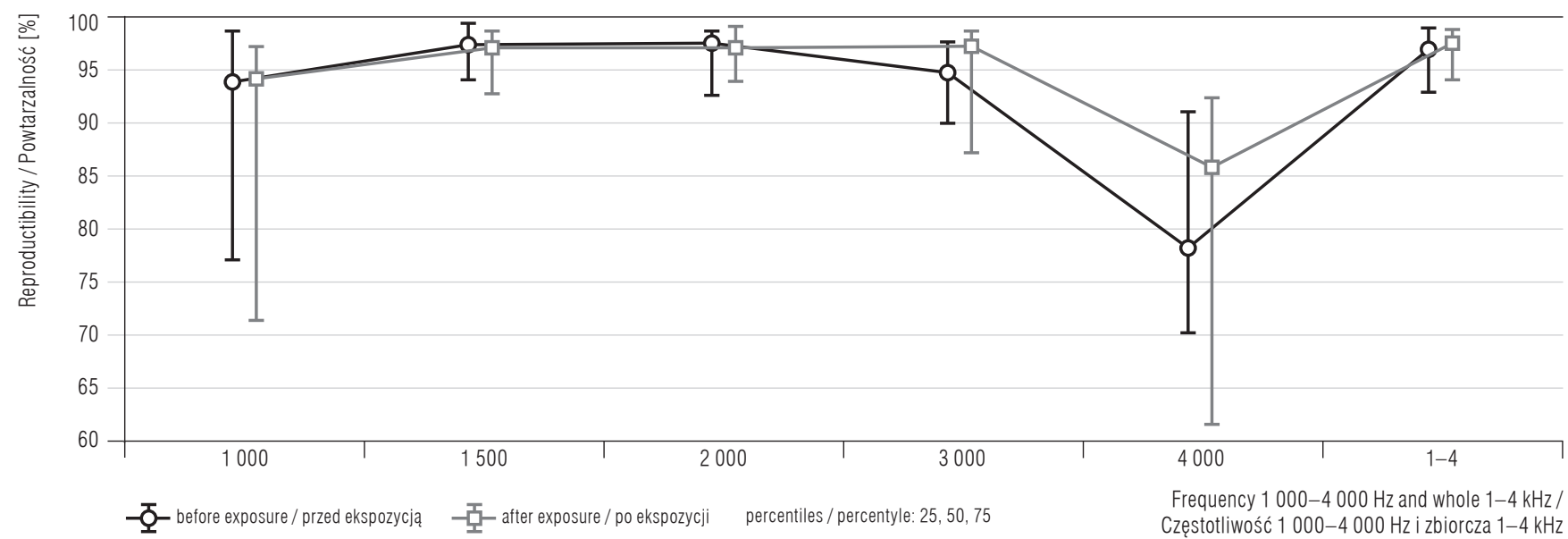

Fig. 3. Transient-evoked otoacoustic emissions (TEOAEs) tests - comparison of reproducibility of responses before and after exposure (playing instruments)

Ryc. 3. Badanie emisji otoakustycznych przejściowych (TEOAE) - porównanie powtarzalności odpowiedzi przed ekspozycją i po ekspozycji (grze na instrumentach)

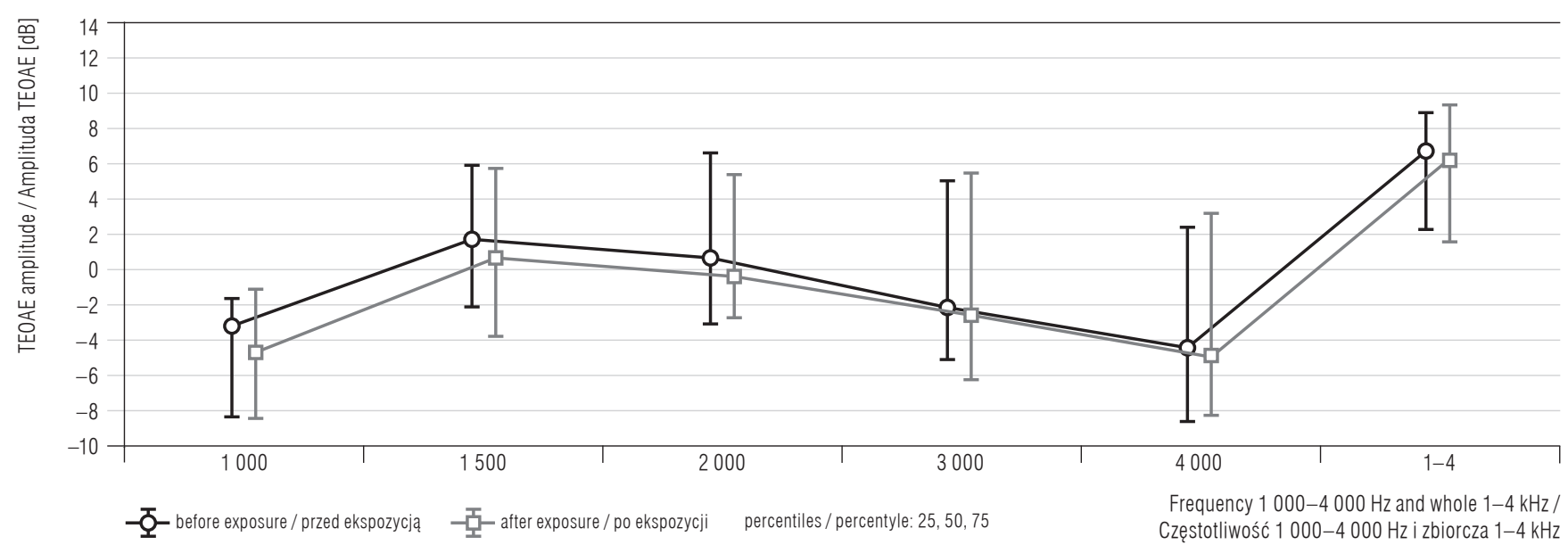

Fig. 4. Transient-evoked otoacoustic emissions (TEOAEs) tests - comparison of the TEOAE amplitude before and after exposure (playing instruments)

Ryc. 4. Badanie emisji otoakustycznych przejściowych (TEOAE) - porównanie amplitudy TEOAE przed ekspozycją i po ekspozycji (grze na instrumentach) 
Table 4. The post-exposure temporary changes in the transient-evoked otoacoustic emissions (TEOAEs) amplitude (at different frequencies and for total response in the frequency band 1-4 kHz) together with results of statistical tests Tabela 4. Czasowe zmiany amplitudy emisji otoakustycznych przejściowych (TEOAE) po ekspozycji (dla różnych częstotliwości i dla odpowiedzi zbiorczej w częstotliwości pasma 1-4 kHz) wraz z wynikami testów statystycznych

\begin{tabular}{|c|c|c|c|c|c|c|c|c|c|c|}
\hline \multirow{3}{*}{$\begin{array}{c}\text { Frequency } \\
\text { Częstotliwość } \\
{[\mathrm{kHz}]}\end{array}$} & \multicolumn{9}{|c|}{$\begin{array}{l}\text { Wilcoxon matched pair Test } \\
\text { Test Wicoxona par skojarzonych }\end{array}$} & \multirow{3}{*}{$\begin{array}{c}\text { Amplitude } \\
\text { reduction } \\
\pm 95 \% \text { CI } \\
\text { Redukcja } \\
\text { amplitudy } \\
\pm 95 \% \text { CI } \\
\text { [dB] }\end{array}$} \\
\hline & \multicolumn{3}{|c|}{$\begin{array}{l}\text { level of noise } \\
\text { poziom szumów } \\
{[\mathrm{dB}]}\end{array}$} & \multicolumn{3}{|c|}{$\begin{array}{l}\text { reproducibility } \\
\text { powtarzalność } \\
{[\%]}\end{array}$} & \multicolumn{3}{|c|}{$\begin{array}{l}\text { TEOAE amplitude } \\
\text { amplituda TEOAE } \\
{[\mathrm{dB}]}\end{array}$} & \\
\hline & $\mathrm{T}$ & $\mathrm{Z}$ & $\mathrm{p}$ & $\mathrm{T}$ & Z & $\mathrm{p}$ & $\mathrm{T}$ & Z & $\mathrm{p}$ & \\
\hline 1.5 & 32.0 & 0.0889 & 0.9292 & 184.5 & 0.1081 & 0.9139 & 117.5 & 1.4731 & 0.1407 & $-0.60 \pm 0.60$ \\
\hline 2 & 14.5 & 1.3251 & 0.1851 & 172.0 & 0.0889 & 0.9292 & 91.5 & 2.1334 & $0.0329^{*}$ & $-0.58 \pm 0.51^{*}$ \\
\hline 3 & 5.0 & 1.8204 & 0.0687 & 188.5 & 0.0120 & 0.9904 & 78.0 & 2.2736 & $0.0230^{\star}$ & $-0.45 \pm 0.37^{\star}$ \\
\hline 4 & 95.0 & 2.0445 & $0.0409^{\star}$ & 132.0 & 1.3694 & 0.1709 & 180.5 & 0.2042 & 0.8382 & $-0.01 \pm 0.99$ \\
\hline
\end{tabular}

CI - confidence interval / przedział ufności, T - test statistics / statystyka testu, Z - standardized to normal distribution test statistic / statystyka testu standaryzowana do rozkładu normalnego.

${ }^{1}$ Whole response in the frequency band of 1-4 kHz / Odpowiedź zbiorcza w pasmach częstotliwości 1-4 kHz.

* Statistically significant / Istotne statystycznie.

The post-exposure temporary changes in the TEOAE amplitude together with the results of the statistical tests are given in the Table 4. Statistically significant reduction of the TEOAE amplitude (for total response and at frequency bands of $2000 \mathrm{~Hz}$ and $3000 \mathrm{~Hz}$ ) was noted after a rehearsal. The deterioration of whole amplitude in the frequency range $1-4 \mathrm{kHz}$ reached $0.7 \mathrm{~dB}$. The comparison of the post- and pre-exposure noise level revealed significant difference only at the frequency of $4000 \mathrm{~Hz}$.

\section{DISCUSSION}

The comparison of the post- and pre-exposure noise level of noise in the test before and after exposure showed only the differences at the frequency of $4000 \mathrm{~Hz}$, which might be due to high frequency hearing losses in the study group. Statistically significant reduction in the TEOAE amplitude (for total response and at frequency bands of $2000 \mathrm{~Hz}$ and $3000 \mathrm{~Hz}$ ) was observed after exposure to excessive sounds during a rehearsal. The aforesaid changes were observed after exposure to orchestral noise at relatively low sound exposure level related to a 8 -h working day $(\sim 80 \mathrm{~dB})$. It should be remembered that the sound pressure levels occurring during collective rehearsals of orchestras are relatively high especially in cases of wind instruments and percussion (Table 1). In the latter case, sound pressure levels may exceed the admissible values of A-weighted maximum sound level $\mathrm{L}_{\mathrm{Amax}}$ and C-weighted peak sound level $\mathrm{L}_{\text {Cpeak }}$ for occupational noise [13].

Earlier, the post-exposure reductions in the TEOAE amplitude were also observed in other studies concerning music exposure $[6,14]$. For example, Libbin [6] - in the case of college marching band members and Santos et al. [14] - in the case of disc jockeys noted temporary variations in TEAOEs in all tested frequencies. However, in those studies, sound exposure levels were higher and amounted to $85-105 \mathrm{~dB}$ and $93.2-109.7 \mathrm{~dB}$, respectively. Also, in the case of $\mathrm{CD}$ players, the TEOAE reduction was observed after exposure to music corresponding to the daily noise exposure $\left(\mathrm{L}_{\mathrm{EX}, 8 \mathrm{~h}}\right) 77-83 \mathrm{~dB}[2,4]$. It should be stressed that the reduction of transient otoacoustic emissions (TEOAE) was determined with high uncertainty. In the future, the size of the study groups should be increased not only in order to reduce uncertainty but also in order to analyze the effects of other risk factors than exposure to orchestral noise.

\section{CONCLUSIONS}

Despite the unknown mechanism which causes temporary variations, it is believed that multiple and repeated exposures which cause temporary changes in hearing 
may lead to permanent hearing loss. Prevalence of temporary reduction of the TEOAE response amplitude supports the statement that the professional musicians are at the risk of hearing deterioration because of their occupational activities, even in the event of exposures to orchestral noise lower than the limit values for industrial noise.

\section{REFERENCES}

1. Zhao F, Manchaiah VKC, French D, Price SM. Music exposure and hearing disorders: An overview. Int J Audiol. 2010;49:54-64, http://dx.doi.org/10.3109/1499202090 3202520 .

2. Jansen EJM, Helleman HW, Dreschler WA, de Laat JAPM. Noise induced hearing loss and other hearing complaints among musicians of symphony orchestras. Int Arch Occup Environ Health. 2009;82:153-64, http://dx.doi.org/ 10.1007/s00420-008-0317-1.

3. Keppler H, Dhoog I, Maes L, D'haenens W, Bockstael A, Philips B, et al. Short-term auditory effects of listening to an MP3 player. Arch Otolaryngol Head Neck Surg. 2010;136(6):538-48, http://dx.doi.org/10.1001/archoto.2010.84.

4. Keppler H, Dhooge I, Maes L, Bockstael A, Philips B, Swinnen F, et al. Evaluation of the olivocochlear efferent reflex strength in the susceptibility to temporary hearing deterioration after music exposure in young adults. Noise Health. 2014;16(69):108-15.

5. Schmuziger N, Patscheke J, Probst R. An assessment of threshold shifts in nonprofessional pop/rock musicians using conventional and extended high-frequency audiometry. Ear Hear. 2007;28(5):643-8, http://dx.doi.org/10. 1097/AUD.0b013e31812f7144.
6. Libbin B. Temporary changes in auditory function among college marching band members University of Maryland. College Park; 2008 [cited 2014 Oct 19]. Availabe from: http://drum.lib.umd.edu/bitstream/1903/8081/1/umiumd-5243.pdf.

7. PN-N-01307:1994. [Noise - Noise limit values in the workplace - Requirements for measurement]. Warszawa: Polish Committee for Standardization; 1994. Polish.

8. ISO 9612:2009. Acoustics - Determination of occupational noise exposure - Engineering method. Geneva: International Committee for Standardization; 2009.

9. Pawlaczyk-Łuszczyńska M, Dudarewicz A, Zamojska M, Śliwińska-Kowalska M. Hearing ability in orchestral musicians. Arch Acoust. 2010;35(4):579-94, http://dx.doi.org/ 10.2478/v10168-010-0044-y.

10. Pawlaczyk-Łuszczyńska M, Dudarewicz A, Zamojska M, Śliwińska-Kowalska M. Evaluation of sound exposure and risk of hearing impairment in orchestral musicians. Int J Occup Ergon. 2011;17(3):255-69, http://dx.doi.org/10.10 80/10803548.2011.11076892.

11. Pawlaczyk-Łuszczyńska M, Zamojska M, Dudarewicz A, Zaborowski K. Noise-induced hearing loss in professional orchestral musicians. Arch Acoust. 2013;38(2):223-34, http://dx.doi.org/10.2478/aoa-2013-0027.

12. ISO 1999:1990. Acoustics - Determination of occupational noise exposure and estimation of noise induced hearing impairment. Geneva: International Committee for Standardization; 1990.

13. Morais D, Benito JI, Almarazb A. Acoustic trauma in classical music players. Acta Otorrinolaringol Esp. 2007;58(9): 401-7, http://dx.doi.org/10.1016/S0001-6519(07)74956-7.

14. Santos L, Thais C, Morata TC, Jacob LC, Albitu E, Marques JM, et al. Music exposure and audiological findings in Brazilian disc jockeys (DJs). Int J Audiol. 2007;46: 223-31, http://dx.doi.org/10.1080/14992020601188575.

The use of the article "Exposure to excessive sounds during orchestra rehearsals and temporary hearing changes in hearing among musicians" is available in Open Access model and permitted under license conditions of Creative Commons Attribution-NonCommercial 3.0 (also known as CC-BY-NC), available at http://creativecommons.org/licenses/by-nc/3.0/pl/deed.en or another language version of this license or any later version of this license published by Creative Commons / Zezwala się na korzystanie z artykułu „Ekspozycja na za głośne dźwięki podczas prób orkiestrowych i czasowe zmiany słuchu muzyków” w modelu open access na warunkach licencji Creative Commons Uznanie autorstwa - Użycie niekomercyjne 3.0 (znanej również jako CC-BY-NC), dostępnej pod adresem http://creativecommons.org/licenses/by-nc/3.0/pl/ lub innej wersji językowej tej licencji lub którejkolwiek późniejszej wersji tej licencji, opublikowanej przez organizację Creative Commons. 